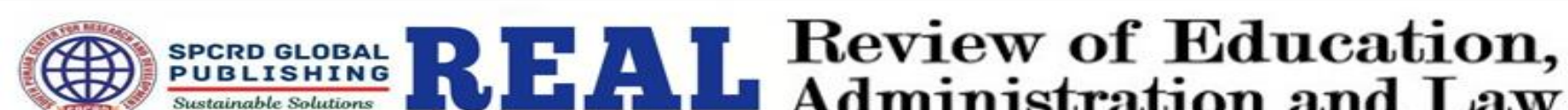 \\ Journal homepage: http://real.spcrd.org ISSN (Print): 2708-1788 ISSN (Online): 2708-3667
}

\section{Performativity analysis in Hyder's the Sound of Falling Leaves}

\author{
${ }^{a}$ Hira Ali, ${ }^{\text {b }}$ Zahir Jang Khattak, ${ }^{\text {c }}$ Abdul Ghaffar Ikram, ${ }^{\text {d }}$ Shehrzad Ameena Khattak \\ a Lecturer, Department of English, University of Sargodha, Pakistan \\ Email: hiramahais15@gmail.com \\ ${ }^{\mathrm{b}}$ Professor, University of Qurtaba, Peshawar, Pakistan \\ ${ }^{c}$ Graduate, University of Sargodha, Pakistan \\ ${ }^{\mathrm{d}}$ Lecturer, University of Karak, Pakistan
}

\begin{tabular}{l}
\hline ARTICLE DETAILS \\
\hline History: \\
Accepted 16 April 2021 \\
Available Online June 2021 \\
\hline Keywords: \\
Gender, Performativity, Speech \\
and Actions, Culture, Society and \\
Subcontinent
\end{tabular}

JEL Classification:

J16,M14, M19

DOI: $10.47067 /$ real.v4i2.145

\begin{abstract}
The present study delves into the concept of gender by applying the theory of performativity on Qurratulain Hyder's story 'The Sound of Falling leaves'. Awareness of the distinction between sex and gender started with the first wave of feminism. Many renowned critics like Virginia Woolf, Simone de Beauvoir, Kate Millet, and Judith Butler have explained this distinction. Writers portray society in text and many writers have tried their hands to depict the role, values, and status of women in a male-dominated patriarchal society. There are many reforms regarding the protection of women and to make women gender better, but we still find a lot of lacks. Gender is defined by society. One is born with sex and becomes a man or woman as he or she starts to identify with society. Gender is constructed on the base of performance of speech and actions which are repeated again and again until it becomes part of our consciousness (Butler, 1990). We have not found any research on this story regarding the application of the theory of performativity. So, this research is designed to examine to what extent the theory of performativity is true by discussing the portrayal of women in this story. This research also analyzes to what extent there is change in a Subcontinent society regarding therole and status of female. Discussion and analysis of text supports the theory of performativity. Instead of many reforms for women rights still woman of subcontinent like 'Tanvir Fatima' are suffering. She becomes victim of conservative society who is not ready to accept modern girls. She is beaten terribly by Khushwaqt and has no say. Her dreams are shattered by both cruel men and women. Further, this study also provides suggestions about how we can improve gender roles and provide healthy atmosphere for both men and women who can play the leading roles for the betterment of the world.
\end{abstract}

(C) 2021 The authors. Published by SPCRD Global Publishing. This is an open access article under the Creative Commons AttributionNonCommercial 4.0 


\section{Introduction}

Gender is always seen as an artificial construct of society because it always has room for improvement. Kirsten Shepherd has beautifully explained in his book Modern drama (2015) that gender can be destroyed and reconstructed with better ingredients into it. One is not born with his or her gender but rather becomes a man or women as he or she comes to the world. Features of masculinity and femininity are attached with the respective genders. Concept of gender varies from society to society. This study is highlighting how women gender is portrayed and seen in the society of subcontinent. There are pact norms of every culture which varies from culture to culture and allow women to wear certain kind of dress, to attend dance shows, to educate themselves, to have free relation with men and there is a certain parameter which decides a woman as pious or not. This study is focusing on these norms and these will be brought onto page through the analysis of Qurratulain Hyder's story, 'the sound of falling leaves'.

There is very less research on cultural issues in the works of Qurratulain so this will be an initiator for delving deep into her works from the perspective of Judith Butler's idea of performativity. Qurratulain has written many stories and novels in Urdu and English and if some of her famous works are not translated then many translators has made the job easy for both English and Urdu readers. This story 'the sound of falling leaves' is also an Urdu story, 'pat jur ki awaz' which is translated by C. M. Naim. She has won many awards. This story has become interesting stylisticians because of the particular style of her writing. But from critical perspective it is left behind. So this research is providing a way for providing new insight into her works and looking through a new mirror.

The distinction between gender and sex has become an interesting issue and many critics are putting their efforts to make this difference more clear by giving new theories and applying it on new texts. This highlighting of difference starts from the first wave of feminism: Virginia Woolf (1927) and Simon de Beauvoir (1949); in the second wave Kate Millet (1970) and in third wave Judith Butler (1990) are at hit list to explain this. Butler sees gender as constructed by society through the repetition of certain actions (1999). Graddol (1983) has said, "the words we speak are also attached with gender" (p.103). Through the analysis of this story we will also be able to explain what type of words are attached with genders particularly words which describes attributes and slangs.

This story is regarding a female protagonist 'Tanvir Fatima' who was educated lady but has faced harsh time in life because of betrayal of her male and female friends. Society imposes strict restrictions on her (females) and does not allow her to live her life fully. If anyone crosses these limits, he has to pay the price for this. This was not enough for her because migration added salt to her injuries. She even herself does not know why she is migrating and whether it will change her condition (female gender). There are some other women in the story who are the friends of her but become more cruel than enemies when she has just visited the cinema and gone to market with Khushwaqt Singh. He leaves her in dilemma. Then another man comes; Faruq sahib who also uses her for his purposes and at last Viqar sahib who marries her again for his interests. But I found crying myself when I read the story because why she became the criticism of her society and why they could not let her (females) live. So this study will highlight all these aspects through the analysis of performativity of women gender in 'the sound of falling leaves'.

Following objectives of this study are:

- Check Portrayal of women in the sound of falling leaves.

- See how an innocent woman is exploited by the norms of society. 
- Evaluate what type of roles women can perform and how it differs from the past attribution to women.

Following research questions of this study:

- How are women portrayed in the sound of falling leaves and Sita betrayed?

- How is an innocent woman exploited by a society?

- What type of roles can women perform and how it differs from the past?

- What does society contribute to the construction of women's' gender?

\section{Review of the Literature}

Study of domination of men over women in patriarchal society is carried out since a century. Feminists have strived for women's rights and status in a cruel society where many privileged things are restricted for males. So, feminism has become the subject of study for many critics and theorists for decades. This is done to bring change and novelty into the gender of women which is viewed with inferiority and lowness. In this regard, literature has proved itself, as usual, worthwhile because writers not only of modern and post-modern times but also from age's writers are depicting and portraying women as seen by society and how they are always constructed and from the men's eye who has held in the shaping of culture (Virginia Woolf, 1929). David Carter (2012) says, "the common goal of feminism is to raise awareness of women's role in all fields of life and to reveal the extent of domination of men over women in all spheres of life" (p.91).

This study is exploring the portrayal of women which is performed or constructed as it is repeated again and again in society. Gender studies are pivotal for analyzing how the woman is seen in society. Judith Butler is not the first one who explained the difference between sex and gender (gender trouble, p.1-25). The study of gender has been done for many years to see gender is constructed by society. There are many ingredients in the women's gender that are missing and it is need of time to add those ingredients and make women for what they deserve. From the first wave of feminism, critics took seriously the distinction between gender and sex. The first critic who spoke about this was Virginia Woolf. She stressed that gender is a social construct and it is not something which is predetermined (Virginia Woolf; 1929; 1938).

Simon de Beauvoir, a famous feminist, also stressed that gender and sex are different things. Sex is something with which a person is born but gender is ascribed or attached with him or her through the social norms, values, and institutions of the society. Simon de Beauvoir says in the second sex, "one is not born but rather becomes a woman" (1989). This means we are the ones who give women those characteristics that form their gender. The basic question is: what type of role, status, and values are attached to women? Kate Millet in Sexual Politics tells that the oppression of women is due to the ideology of society which is itself designed by males (2000). If we see women of the nineties, we find that the women are considered inferior and they are subordinated. But then the flux kept on changing and now we find women in all fields of life. Critics began to focus on women writers because they truly reflected women.

Judith Butler, a renowned feminist of the third wave, explained many concepts related to gender and sex. She (1999) equals gender with the concept of performativity (gender trouble: feminism and the subversion of identity). She challenges the conventional notion of women and said that everything attached to women is the beauty of society. She says, "gender is constructed through the performance of speech and action" (1999). An action that we do is already being done before our birth and we accept that action or speech without consideration; whether it is bad for our gender or not. If we do anything out of circle we are always cursed and have to face critical pressure from society and this is especially 
restricted for women. This criticism is then not from the opposite sex but also from the same gender (women) that are too reserved and see everything myopically. Women got many rights with the advent of the twentieth-century but still, women are facing hardships in many societies and Subcontinent is one of them. We are going to analyze through the text of Qurratulain Hyder whether there is any change in the gender of women or they are still living in dark colors and the plight of women.

Qurratulain Hyder was born into an intellectual family. Her parents were already attached to the world of literature and had produced magnificent pieces of work of art. Naim says (1999), "her parents were already striving for the rights of women especially her mother who was liberal and made effort to bring Muslim women close to education" (pp.1-20). She has seen migration with her eyes and how it rampant the culture and makes people suffer. She was born in such a society where women are considered as the property of men. There were very strong restrictions on women and men enjoyed every pleasure of life. They were confined to four walls of their homes. But we do not find any such kind of women in her work but the woman who has stepped out of their houses and suffered a lot because of this act. Qurratulain Hyder tries to portray a few characters and uses the first-person point of view so we should be clear about the protagonists' actions, thoughts, and feelings. She is one of the renowned writers of Pakistan and had won many of the awards. She has done wonders in Urdu and English language. She was not a short story writer or novelist but also a famous journalist. She gave many interviews on the BBC. There is a lot of research regarding the style of her writings but we are not able to find any material on the analysis performativity of genders in her works. So, this can be a starter for analyzing how subcontinent writers are portraying male and female characters and what type of liberties culture allows them.

\section{Research Methodology}

This study is qualitative. We are applying the theory of Performativity on Hyder's story 'The sound of falling leaves'. Performativity is the eye-catching concept of Judith Butler in which she puts forward all the concepts related to the difference of gender and sex. She has continued the ideas of Virginia Woolf, Simon de Beauvoir, Kate Millet, and many other feminist critics. She defines performativity as the performance of gender that is based on the imitation or repetition of actions and words of the speech (Gender Trouble). So, this study will highlight the gender of women through this text; what type of words are attached to their gender which describes their attributes or the slang words, and what are their dresses and do they have the same freedom as men or not. This study is also emphasizing; which gender is exploiting the other and if some wrong is done which one has to face strong criticism.

\section{Discussion and Analysis}

Many bottles of inks are used by the critics to give an analysis of texts and leaving for the world a better view through which we can bring prosperity in society. Both males and females are the pillars of society and they both are needed for building a good environment. We are analyzing the story 'the sound of falling leaves' by applying the theory of performativity. We notice that a person is born with any of the sex but what he or she becomes later is on the base of gender. Gender is defined by the roles, values, and norms specific for any sex and which are defined by society. Even our dresses, our duties as one member of the family are restricted, who has to do the cooking, if some wrong action is done than who is more responsible for it and especially the language used to explain the attributes or adjectives of any gender. So, this research is trying to focus on gender portrayal and what type of deep meanings she wants to give through her work which can make gender better.

The first paragraph of the story reveals a lot; as the protagonist 'Tanvir Fatima' is purchasing 
something from the vegetable vendor who is standing in front of the street. This means cooking is attached to females. Hyder has used the first-person narrative and Tanvir is telling the story in the first person but later on, there will be a shift to the third person. Fatima says, "As I argued with the vendor my mind was busily planning the evening meal" (Hyder, p.3). This shows the psychological condition of Fatima who is thinking constantly about the meal. But on the other hand, her husband is standing in front of the mirror and with no tension is humming a tune. She describes Viqar sahib, "standing in front of the dull mirror over the chipped sink, admiring his face and shaving" (Hyder, P. 4). So from the first paragraph, we are noticing the difference in gender roles. He is standing in front of the mirror, doing the male action of shaving and she is planning for a meal.

From the third paragraph onward, Hyder has used the flashback technique to reflect on the life of Tanvir Fatima. When she wrote the story many fanatical views of the society of the subcontinent have already changed. Education which was restricted to just male members of the family was now open to females as well. Tanvir was an educated girl and beautiful. She says, "I was a healthy girl and people were talking of my beauty" (p.4). This was a trend in the society that male members would choose girls on the base of beauty. She has been selected but her mother rejected the proposal because her mother like the mother of most other girls had loftier and big plans. This shows how female gender has to submit to male choices if their mothers agree. One thing to notice is that Tanvir says, 'my mother has loftier plans' which means her mother is judging the relation on the base of wealth like common mothers.

Then she talked with her friend who has instantly come to the place and gives her information about every old friend of ours. This is showing that females have an eye on each and everything and nothing can escape their eyes. Fatima used a traditional expression for women like, 'women have an intelligence service, it can put even Interpol to shame' (Hyder, p.4). Here Hyder has given us the clear difference of gender in a comic way that women know everything. They know how the other friend is living and in which condition she is. Then, Fatima tells about her family. We find the gender roles of Muslim society that she has to observe "strict Purdah". Here we have to note why she is using an adjective like strict with purdah because her family was not too rich and could also be conservative which makes different roles for her as compared to other females of a rich family. But she was their only child which gave her the chance to study. She says, 'but as my parents only daughter, I was their darling' (p.4). Had the situation be otherwise, like she had brothers and sisters then she would not be able to enjoy all the luxuries because of the restrictions on her gender.

We find the constant use of "black Burqas" in this story as well as in her some other works. Fatima says, 'covered from head to toe in black burqas'(p.5). This shows how female students in college, where there were other female students, have to play and do everything while covering them completely. Intentionally or unintentionally, the writer leaves many clues for the coming generation of readers to interpret. Here 'head to toe' gives us clearly that Qurratulain is mocking the restrictions on females. This mocking will become more severe as we proceed further in the story. Now, if we see how Hyder has described Fatima's body and the adjectives which she used for her are completely different from male genders. She says, 'I was a rare beauty... one in a thousand: fair, translucent skin, reddishblond hair, tall and slender' (p.5). These are the words associated with a beautiful female but for handsome males, Hyder has provided different characteristics. In the subcontinent, a handsome male is who has shiny teeth, having good height, black color, and solid mustaches and this is the clear gender difference attached to physicality.

Females are always swayed by Sentiments, adventurous life, and emotions and Fatima has also 
become the victim of this (she gives the reference of Arabian Nights). She cannot enjoy many pleasures as rich girls. The story is going towards the introduction of the character that will change her life completely. Many girls of the college go out and relish their lives with boys but boys are not blamed just girls are taunted and called with bad names. Fatima tells us that society takes those girls as 'strange and mysterious'. There are some norms for every gender and if they are going to deviate from these, then a hell of criticism is waiting for them. Those girls even have not done anything wrong but Sarla says, "our society is not prepared to accept modern, educated girls" (Hyder, p.6). Society is ready to give every kind of freedom to men but not minute freedom of even selecting a partner with their wish. Fatima also becomes part of the list of those girls. She has just visited a market and gone to the cinema with Khushwaqt Singh (a monster). But her favorite friends start calling her the mistress of him (whore). This behavior of society instigates many girls to the wrong side.

Marriage is a big problem in the subcontinent. Fatima was Muslim and she cannot marry him because he was Sikh. This shows restrictions of institutions on genders and also a generalization that Indians who marry Muslim women divorce them with a year. Khushwaqt started to beat her and very badly and this shows his love towards her (love is equated with beating). Woman's gender has faced this patriarchal pressure from centuries and in the subcontinent still, that pressure is present. A man like Khushwaqt would use every means to pursue their evil desires. Fatima could do nothing for herself. He took another woman with her and spoiled the future of her. But her hostel friends were worse than him because they treated her like a ghost. She says, "I hear them saying me nympho" (Hyder, p.9). Now, a girl who was considered 'Rani' of her college was not thought of anything. Her brighter chance of marrying has also become dumb. She marries Faruq who was a dark and old aged person. He was already married and had children. The point to consider why he marries her is again due to his (male) selfish nature because he was in search of an educated lady.

Migration adds more misery to her life; Faruq has left because his purpose was fulfilled. Now, Viqar Sahib who always maltreats his wife becomes her husband. Fatima says, "Viqar treated his previous wife very badly, and she runs away but always comes back" (Hyder, p.15). This shows how males are exploiting female gender and how females are unable to help themselves. This all is because of the systems devised by a cruel society. Fatima is left with no future and her education is not helpful to her. Qurratulain Hyder ends this story on crucial thoughts of Fatima. When she lays on the bed she always thinks of Khushwaqt who is responsible for all her turmoil and trouble which can also refer to the male gender.

\section{Conclusion}

The above discussion and analysis show that gender is the construction of society. Norms, mores, and laws for any gender are also defined by these societies. It is very difficult to step out of the conservative circles of our surroundings and if we try we will bear the burden of it till death. We have found the words attached to females as rani, beautiful, slim, and pink colored. Women wearing saris are considered elegant. All the friends of Fatima were well educated including herself, but now the problem is how much this education has helped in the betterment of women. Fatima who is the protagonist of this story and also the protagonist of Subcontinent society is crumbled under the tyrannical rules and regulations of society. She is beaten by Khushwaqt for not acting on his demands and in response society taunts her not him. When she has become the victim of the cruelty of one man then Faruq and Viqar also put in their shares because the male gender in this text is proved to be just taking care of their needs and demands. Fatima has no say for herself and her gender. The troublesome aspect is that the woman who is handled badly by men is also deprived of the support of her friends. This is the need of the time that in our society we give freedom to women because their freedom will lead to the 
betterment of families and society. If nothing can be done then at least beating to females should not be allowed. So make your society better by giving equality to each gender.

\section{References}

Beauvoir, Simon de. The Second Sex. New York: Vintage Books, 1989, p. 283.

Butler, Judith. Gender Trouble: feminism and the subversion of identity. New York: Routledge, 1999, pp. 1- 128.

Butler, Judith. Performative acts and gender constitution: An essay in phenomenology and feminist theory. Theatre journal. 40 (4): 519-531. Doi:10.2307/3207893, 1988.

Butler, Judith. Bodies that matter: on the discursive limits of sex. New York: Routhledge. ISBN 978-0415-90365-3, 1993.

Carter, David. Literory theory. Old castle books. 2012. ISBN 1842438131, 9781842438138, pp.91-100.

Graddol, David, and Joan Swann. Gender voices. Oxford : Blackwell, 1989, p.103.

Hyder Qurratulain. Season of Betrayal. New Delhi: kali for women, 1999. ISBN: 8186706011, pp. 1-20.

Millet, Kate. Sexual Politics. Urbana: University of Illinois Press, 2000.

Shepherd, Kirstein. Modern Drama: A very short introduction. Oxford: Oxford university press. 2015, p.11.

Woolf, Virginia. A room of one's own. New York: Harcourt, Brace abd Company, 1929.

Woolf, Virginia, and Naomi Black. Three Guineas. Oxford: Published for the Shakespeare Head Press by Blackwell Publishers, 2001. 